\title{
Soil-plant characteristics in an age sequence of coronilla varia L. plantations along embankments
}

\author{
$\mathrm{Y}, \mathrm{Li}^{1,2}, \mathrm{Z}, \mathrm{Gao}^{1,2^{*}}, \mathrm{~L} . \mathrm{Tang}^{1,2}$ \\ ${ }^{1}$ Institute of Soil and Water Conservation, Northwest A\&F University, Yangling 712100, PRChina. ${ }^{2}$ Institute of \\ Soil and Water Conservation, ChineseAcademy of Sciences and Ministry of WaterResources, Yangling 712100, \\ PR.China. *Corresponding author: gzl@ms.iswc.ac.cn
}

\begin{abstract}
Objectives: Coronilla varia L., a leguminous herb, is widely used in vegetation restoration programs on road embankments to enhance soil nutrients. Our hypothesis is that, under identical climatic conditions, plant and soil properties are determined by the slope aspect and stand age of legume plantations.

Methods: We collected soil samples and investigated plant diversity in an age sequence of 0-, 4-, 10- and 20-year-old C. varia L. plantations and natural grasslands.

Results: Stand age, rather than slope aspect, was found to be the main factor influencing the soil and plant feedback on the embankments. Planting $C$. varia L. on the embankments could enhance soil nutrients and improve the soil quality to the level of a natural grassland after 20 years of plantation. The plant diversity and species number were steady after $C$. varia L. had been established for 10 years.

Conclusions: Planting C. varia L. on embankments is an effective method for enhancing soil nutrients and maintaining ecosystem stability in the Guanzhong Basin, China.
\end{abstract}

Keywords: Revegetation, grassland, roadside, plant-soil interface

\section{Introduction}

Road construction is a major factor in global land-use change, and it produces numerous ecological effects. Roads and the areas adjacent to road construction zones cover $15-20 \%$ of American land surfaces (Forman, 2000), and to accomplish road construction, heavy equipment, such as bulldozers, excavators, and dump trucks, is used to excavate buried stream channels and reshape disturbed hill slopes (Madej et al., 2012). Road construction exposes a substantial amount of bare land, and it impacts the physical and ecological properties of the landscape by changing the dynamics of plant and animal populations, altering the flow of materials, introducing exotic species, and changing the amount of available resources, such as light, water and nutrients (Angold, 1997; Coffin, 2007). The road-effect zone is highly asymmetrical because of the directional flow of materials and the spatial patterns of the different sides of a road, resulting in complex boundaries (Forman and Deblinger, 2000).

The revegetation of embankments is an effective method for maintaining road stability and controlling 
erosion (Grant et al., 2011), and road slopes are usually planted with legumes to improve soil nutrient content because of the $\mathrm{N}$-fixing capability and high yield of this plant family (Jáuregui et al., 2013; Yuan et al., 2015). Different features of road development have different negative consequences for the environment (Liu et al., 2008), and slope aspect is a primary factor affecting plant composition and soil properties (Warren and Robert, 2010). Several studies have concluded that the variation in soil and plant properties between two contrasting slope is the result of differences in the amount of incident solar radiation, light intensity, soil and air temperature, humidity, soil moisture, and duration of growing periods (Maren et al., 2015). Recent studies have investigated soil and community properties between north and south aspects, but their results have been controversial (Sternberg and Shoshany, 2001; Bochet and Garc-Fayos, 2004; Warren and Robert, 2010; Maren et al., 2015; Yuan et al., 2015). The link between species traits and soil processes provides a strong argument for considering the potential impact of this relationship on soil and plant restoration (Callaham et al., 2008; Eviner and Hawkes, 2008; Yuan et al., 2015). Numerous studies of roadsides have indicated a relationship between the spread of non-native plant species and soil nutrient levels, and have shown that the disruption of the chemical environment along roads affects plant growth, species diversity and composition, especially in nutrientpoor ecosystems (Cape et al., 2004; Forman, 2000; Heneghan et al., 2008; García-Palacios et al., 2011). Plant-soil interactions are important for understanding the role of biotic control in the functioning of roadside ecosystem, but little is known about these links in the context of ecosystem restoration and succession (Merino et al., 2015; García-Palacios et al., 2011). Changes in plant community composition along a successional gradient exert the strongest influence on erosion control, soil carbon storage and nitrogen accumulation (Jimenez et al., 2011; García-Palacios et al., 2011), but the mechanisms responsible for community succession following the introduction of legumes on road slopes are largely unknown. Therefore, slope aspect and the duration of restoration on embankments have been primarily considered in the context of their direct effects on the feedback between plants and soil. Our hypothesis is that, in the absence of pressure by large herbivores and under identical climatic conditions, plant diversity and soil properties are determined by the slope aspect (sunny aspect, shady aspect or no slope) and the age of the legume stand. Our goals are to assess the effects of different stand ages and slope aspects on the soil physical-chemical properties and plant diversity of embankments and propose an interaction function between the soil and vegetation.

\section{Materials and Methods}

The field study was conducted along the sides of a district highway between the regions of Xi'an and Niubei $\left(33^{\circ} 19^{\prime}-35^{\circ} 12^{\prime} \mathrm{N} \cdot 106^{\circ} 37^{\prime}-110^{\circ} 14^{\prime} \mathrm{E}\right)$ of central Shaanxi Province, China (Figure 1). This area lies to the west of the Guanzhong Basin and rises from 376 to $506 \mathrm{~m}$ above sea level. The region has a continental climate with an annual rainfall of 550-650 mm, and the mean temperature is 24.5 to $26.7^{\circ} \mathrm{C}$ and -2 to $-1^{\circ} \mathrm{C}$ in summer and winter, respectively. The soil is derived from loess parent materials and is classified as an Earth-cumuli-Orthic Anthrosol (Sun et al., 2013). The district highway from Xi'an to Niubei consists of three highways: the highway around Xi'an, the highway from Xi'an to Baoji, and the highway from Baoji to Niubei, and these three highways were built in different years. The highways around Xi'an, from Xi'an to Baoji and from Baoji to Niubei were built in 2003, 1993 and 2009, respectively, and the 
revegetation projects of the embankments of the three highways included legume stands of 10 years (S10), 20 years (S20), and 4 years (S4) of age. After removing all of the herbs, the embankments of all three high ways were planted with Coronilla varia $\mathrm{L}$ by seeding, and the addition of a $30 \mathrm{~cm}$ layer of topsoil was used to encourage the establishment of plant cover on the study road slopes.
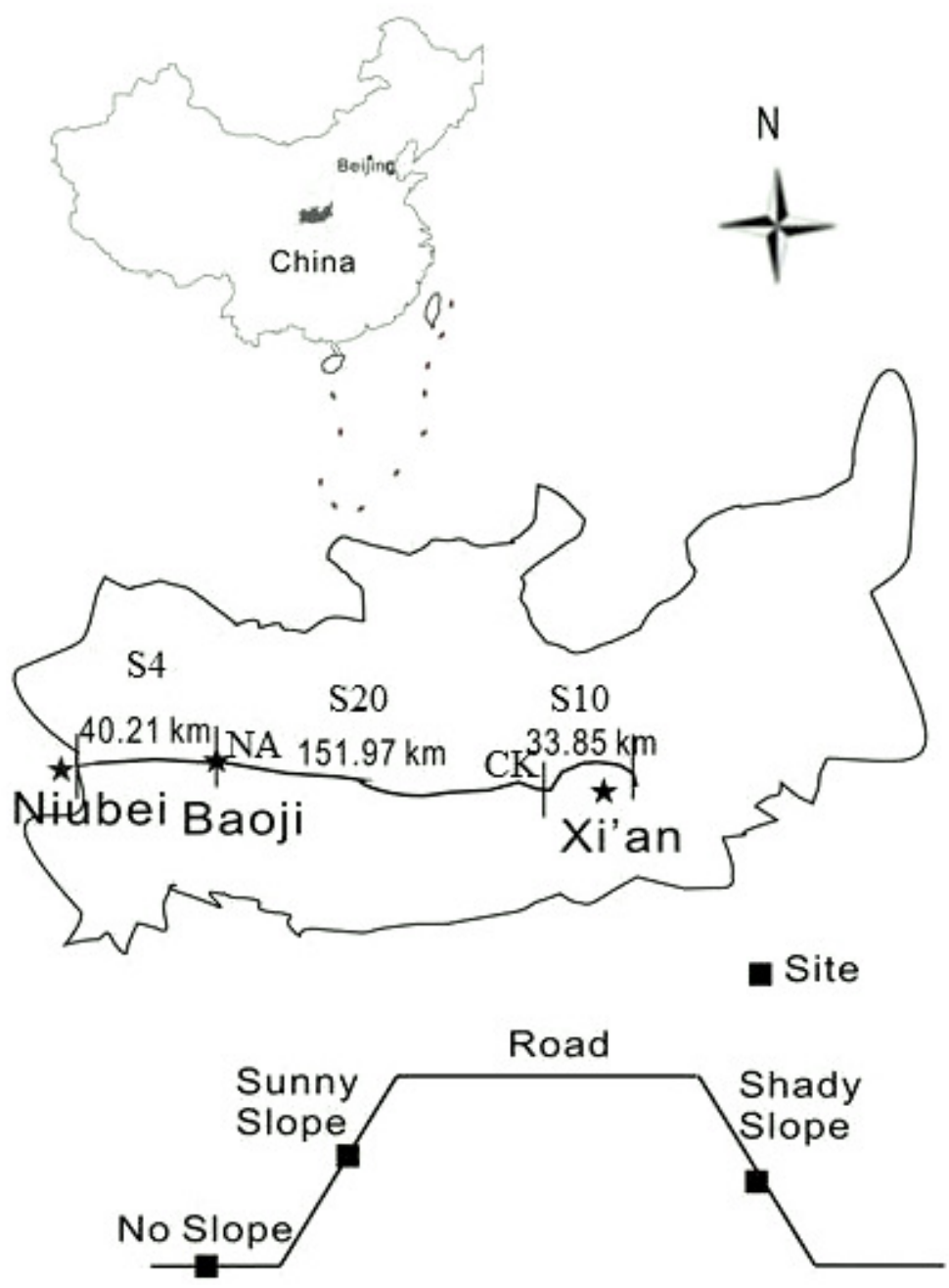

Figure 1. Location of the five treatments in an age sequence of 0- (CK), 4- (S4), 10- (S10) and 20- (S20) year-old Coronilla varia L. plantations and natural grasslands (NA) from study highways in the Guanzhong Plain, China, as well as, the sampling sites along the embankments. 


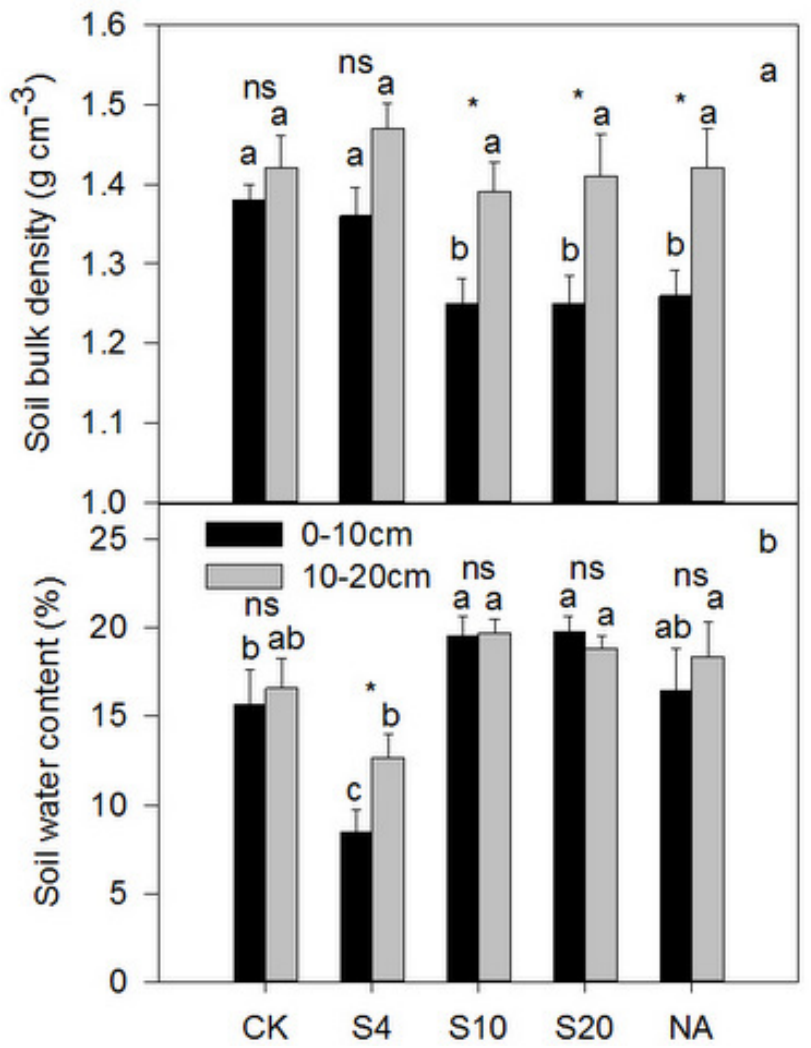

Figure 2. Mean soil water content (b) and bulk density (a) in the $0-10 \mathrm{~cm}$ and $10-20 \mathrm{~cm}$ soil layers in an age sequence of 0- (S0), 4- (S4), 10- (S10), and 20-year-old (S20) Coronilla varia L. plantations and natural grassland (NA). Error bars indicate the standard error of the mean, and bars with different letters above them are significantly different at $\mathrm{P}<0.05$. Significant differences between the different soil depths are indicated by symbols: *: $\mathrm{P}<0.05$; ns: not significant different. 


\subsection{Experimental design and sampling}

A common method to study vegetation restoration is to monitor plants and soils under similar climatic conditions and follow the sequence of vegetation development. The'space-for-time' substitution makes the critical assumption that each site in the sequence differs only in age and that both the abiotic and biotic components of each site have experienced the same history (Wang et al., 2015). In this study, we selected the three highways with revegetation stands of different ages: S4, S10 and S20, and we also selected areas containing bare land with newly built topsoil (CK) and natural grassland (NA) near the studied highways as controls. The distances between the CK, NA and the selected highways were no greater than 1 $\mathrm{km}$. Therefore, there were five treatments in this study, and in August 2013, nine sites were established along the embankments in each of the five treatments: three sites with a sunny slope, three sites with a shady slope and three sites with no slope. The sites with the same slope aspect were separated by $5 \mathrm{~km}$. At each site, we established a $50 \mathrm{~m}$ line transect along the road in the middle of the embankments, and five quadrats $(1 \times 1$ $\mathrm{m})$ were separated by $10 \mathrm{~m}$ on each transect. In total, we surveyed forty-five quadrats in each treatment.

\subsection{Soil sampling and analysis}

We selected 135 soil sampling quadrats along the three highways (S20, S10 and S4), and 90 quadrats in the CK and NA at topsoil depths of $0-10 \mathrm{~cm}$ and $10-20 \mathrm{~cm}$. Soil bulk density (BD), porosity and soil water content (SWC) were measured from soil cores (volume, $100 \mathrm{~cm}^{3}$ ) from both topsoil layers using the volumetric ring method. Soil samples were collected from five points in the quadrats of each plot, and the samples from the same layers were mixed together to produce one sample per plot. All of the soil samples were air-dried and then passed through a $0.14 \mathrm{~mm}$ sieve for further analysis. Soil organic matter (SOC), available phosphorus (AP), ammonia nitrogen (AN) and nitrate nitrogen $(\mathrm{NN})$ were analyzed following the methods recommended by the Agricultural Chemistry Specialty Council of the Soil Science Society of China (Council, 1983). Total Nitrogen (TN) was measured with the Kjeldahl method using a distilling unit (Tecator, Höganäs, Sweden), and total soil phosphorus (TP) was determined by perchloric acid digestion (Olsen SR, 1982).

\subsection{Plant properties}

In each quadrat, we determined the species number (S) and the number of individuals of each species. The Shannon-Wiener diversity index $(H)$ and Menhinick index $(M e)$ values of the S4, S10, S20 and NA treatments were calculated as follows:

Shannon-Wiener diversity index $(H)$,

$H=-\sum_{i=1}^{s}(P i \ln P i)$

Menhinick index $(\mathrm{Me})$,

$$
M e=S / \sqrt{N},
$$

Where $H$ is the Shannon-Wiener diversity index; $P i$ is the ratio of the individual number of species, $I$, in the sample plot; $S$ is the total species number of the grassland community; and $N$ is the total number of each individual species.

\subsection{Data analysis}

All of the data were expressed as the mean \pm the standard error (SE) of the three sites. The $H, M e, S$, plant cover and SWC, BD, SOC, TN, TP, AP, AN and NN data were 
analyzed by two-way analysis of variance (ANOVA) to determine the main effects and interactions of the different restoration ages (CK, S4, S10, S20 and NA) and aspects at $\mathrm{P}<0.05$. One-way ANOVA followed by a least significant difference (LSD) test $(\mathrm{P}<0.05)$ was used to examine the effects of restoration ages on the soil and plant properties, and paired sample t-tests were used to analyze the effects of soil depth on the soil properties. Pearson correlation analysis was performed the relationship between the soil chemical-physical properties and plant characteristics. All of the statistical analyses were conducted with the statistical software program SPSS 11.5 for Windows (Chicago, Illinois, USA).

\section{Results}

\subsection{Response of soil and plant properties}

The ANOVAs indicated that there were significant impacts $(\mathrm{P}<0.05)$ of restoration age on the soil and plant properties, but no effect of slope aspect $(\mathrm{P}>0.05)$. In addition, there were no significant effects $(P>0.05)$ of stand age $\times$ slope aspect interactionon the soil properties and plant diversity (Table 1). These analyses indicated that the responses of the soil and plant properties were dependent on restoration age and not on slope aspect.

Table 1. Effects of stand age (Age) and slope aspect (Asp) on the Shannon-Wiener index (H), Menhinick index $(\mathrm{Me})$, species number $(S)$, plant cover, soil water content (SWC), soil bulk density (BD), soil organic carbon (SOC), total nitrogen (TN), total phosphorus (TP), available phosphorus (AP), ammonium nitrogen (AN), and nitrate nitrogen $(\mathrm{NN})$.

\begin{tabular}{|c|c|c|c|c|c|c|c|c|c|}
\hline \multirow[t]{2}{*}{ Factors } & \multicolumn{3}{|c|}{ Age } & \multicolumn{3}{|c|}{ Asp } & \multicolumn{3}{|c|}{$\begin{array}{l}\text { Age*As } \\
p\end{array}$} \\
\hline & $\mathrm{df}$ & $\mathrm{F}$ & $\mathrm{P}$ & $\mathrm{df}$ & $\mathrm{F}$ & $\mathrm{P}$ & $\mathrm{df}$ & $\mathrm{F}$ & $\mathrm{P}$ \\
\hline$H$ & 3 & 3.381 & 0.023 & 2 & 1.579 & 0.227 & 6 & 1.194 & 0.343 \\
\hline $\mathrm{Me}$ & 3 & 4.418 & 0.013 & 2 & 0.863 & 0.434 & 6 & 1.129 & 0.376 \\
\hline$S$ & 3 & 11.174 & $<0.001$ & 2 & 2.598 & 0.095 & 6 & 1.731 & 0.157 \\
\hline Cover & 3 & 7.122 & 0.001 & 2 & 3.089 & 0.065 & 6 & 3.952 & 0.007 \\
\hline SWC & 4 & 6.680 & 0.001 & 2 & 0.465 & 0.633 & 8 & 0.381 & 0.923 \\
\hline $\mathrm{BD}$ & 4 & 4.212 & 0.008 & 2 & 0.494 & 0.615 & 8 & 0.893 & 0.535 \\
\hline SOC & 4 & 9.914 & $<0.001$ & 2 & 2.411 & 0.107 & 8 & 0.59 & 0.778 \\
\hline $\mathrm{TN}$ & 4 & 10.235 & $<0.001$ & 2 & 2.111 & 0.139 & 8 & 0.509 & 0.840 \\
\hline $\mathrm{TP}$ & 4 & 5.718 & 0.002 & 2 & 0.733 & 0.489 & 8 & 0.219 & 0.985 \\
\hline AP & 4 & 4.963 & 0.003 & 2 & 0.610 & 0.550 & 8 & 0.909 & 0.522 \\
\hline AN & 4 & 2.413 & 0.071 & 2 & 2.957 & 0.067 & 8 & 0.189 & 0.989 \\
\hline $\mathrm{NN}$ & 4 & 5.243 & 0.003 & 2 & 0.845 & 0.440 & 8 & 1.262 & 0.300 \\
\hline
\end{tabular}


The analysis of soil physical properties revealed clear trends in $\mathrm{BD}$ and SWC along the plantations temporal gradient (Figure 2). It the $0-10 \mathrm{~cm}$ layer, $\mathrm{BD}$ in the CK, S4, S10, S20 and NA were 1.38, 1.36, 1.25, 1.25 , and $1.26 \mathrm{~g} \mathrm{~cm}^{-3}$, respectively, and $\mathrm{BD}$ decreased significantly as the standage increased. The SWC was lowest in S4, and no significant differences were found among the CK, S10, S20 and NA treatments. The results indicated that after 20-years restoration, the soil physical properties of the embankments were similar to those of natural grassland.

The establishment and development of C.varia $\mathrm{L}$. resulted in enriched $\mathrm{SOC}, \mathrm{TN}, \mathrm{NN}, \mathrm{AN}$, and TP in the highway embankments and decreased AP $(\mathrm{P}<0.05)$ (Figure 3). The SOC at the soil depth of $0-10 \mathrm{~cm}$ increased from S4 $\left(5.66 \mathrm{~g} \mathrm{~kg}^{-1}\right)$ to $\mathrm{S} 20\left(25.45 \mathrm{~g} \mathrm{~kg}^{-}\right.$ ${ }^{1}$ ), and SOC in the S20 treatment was similar to that in NA. In the 10-20 cm layer, SOC increased from
$4.94 \mathrm{~g} \mathrm{~kg}^{-1}$ in S4 to $13.73 \mathrm{~g} \mathrm{~kg}^{-1}$ in S20 (Figure 3a). Compared to $\mathrm{CK}, \mathrm{TN}$ in $\mathrm{S} 20$ increased 2.6-fold in the $0-10 \mathrm{~cm}$ layer and 1.8 -fold in the $10-20 \mathrm{~cm}$ layer (Figure 3b). After C.varia L. had been established for 20 years, the levels of SOC, TN, TP and NN were significantly higher than those in the S4 and CK treatments. In contrast, AP decreased gradually and became nearly constant after C.varia L. stood for 10 years (Figure 3d).

Plant cover increased significantly from S4 to S20 $(\mathrm{P}<0.05)$, but $H, S$ and $M e$ decreased significantly $(\mathrm{P}<0.05$, Table 2). After four years of plantation with $C$. varia $L$., the greatest $\mathrm{S}$ value was 13.33 , and there were approximately 12 other species. Compared with the S4 treatment, the number of additional species in S10 was approximately 5, and no change occurred in the 10 subsequent years, indicating that the ecosystem began to stabilize after 10 years of restoration with C. varia $\mathrm{L}$.

Table 2. Cover, species number $(S)$, Shannon-Wiener index $(H)$, and Menhinick index $(\mathrm{Me})$ in an age sequence of 4- (S4), 10- (S10), and 20-year-old (S20) Coronilla varia L. plantations and natural grassland (NA). The different letters indicate significant differences at $\mathrm{P}<0.05$.

\begin{tabular}{|c|c|c|c|c|c|}
\hline Type & Main species & Cover $(\%)$ & $S$ & $H$ & $\mathrm{Me}$ \\
\hline$\overline{\mathrm{S} 4}$ & $\begin{array}{l}\text { Coronillavaria,Setariavir } \\
\text { disBeauv. }\end{array}$ & $77 \pm 6 b$ & $13.33 \pm 1.28 \mathrm{a}$ & $1.39 \pm 0.15 \mathrm{ab}$ & $0.23 \pm 0.08 \mathrm{ab}$ \\
\hline $\mathrm{S} 10$ & $\begin{array}{l}\text { Coronillavaria, Cyperusr } \\
\text { otundus, }\end{array}$ & $92 \pm 3 \mathrm{ab}$ & $6.56 \pm 0.77 b$ & $1.12 \pm 0.11 \mathrm{~b}$ & $0.19 \pm 0.06 b$ \\
\hline $\mathrm{S} 20$ & $\begin{array}{l}\text { Coronillavaria,Echinoc } \\
\text { hloa crus-galliBeauv. }\end{array}$ & $98 \pm 1 \mathrm{a}$ & $6.67 \pm 0.73 b$ & $1.13 \pm 0.15 b$ & $0.21 \pm 0.07 b$ \\
\hline NA & $\begin{array}{l}\text { Acalyphaaustralis,Imper } \\
\text { atacylindricaBeauv. } \\
\text { Dendranthemaindicum }\end{array}$ & $76 \pm 11 b$ & $15.56 \pm 2.58 \mathrm{a}$ & $1.72 \pm 0.18 \mathrm{a}$ & $0.96 \pm 0.32 \mathrm{a}$ \\
\hline
\end{tabular}



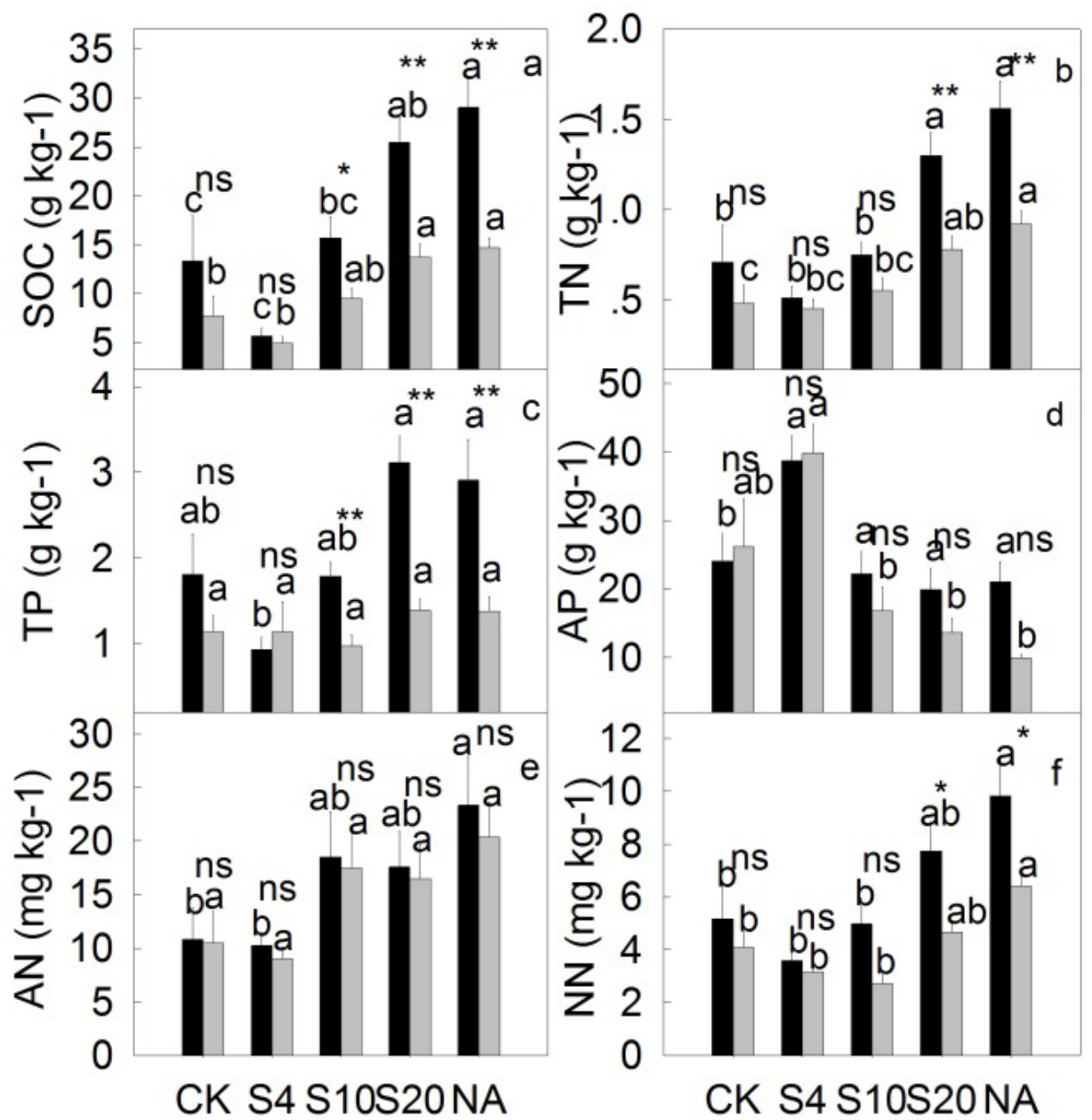

Figure 3. Soil organic carbon (SOC), total nitrogen (TN), total phosphorus (TP), available phosphorus (AP), ammonium nitrogen (AN) and nitrate nitrogen (NN) in 0-10 cm (black bars) and 10-20 cm (gray bars) soil layers. Significant differences among the five treatments with different stand ages are labeled with different lower case letters $(\mathrm{P}<0.05)$. Significant differences between the different soil depths are indicated by symbols: **: $\mathrm{P}<0.1$; *: $\mathrm{P}<0.05$; ns: not significantly different. 


\subsection{Plant-soil interaction}

A correlation analysis of the soil parameters of the $0-10 \mathrm{~cm}$ layer with stand age, plant cover and diversity showed that the soil physicochemical properties were strongly interrelated, and plant diversity was also positively interrelated. However, the relationship between the soil and plant properties was not significant. The results showed that $H$, $M e, S, \mathrm{SOC}, \mathrm{TN}, \mathrm{TP}, \mathrm{AN}$, and $\mathrm{NN}$ were positively related with stand age, but slope aspect and AP were not significantly related to any of the other factors. Furthermore, BD was significantly negatively correlated with SOC, TN, TP, AN, and NN.

\section{Discussion}

In contrast to our expectations, there are on significant differences in the soil and plant properties between the north-facing and south-facing slopes and these results are not consistent with most of the findings from previous research or with the general pattern usually reported for soil properties. Typically, soils have been found to be more fertile on north-facing slopes (Maren et al., 2015). So, previous studies have concluded that slope aspect is an important driver of soil and plant processes because the different aspects have different SWC, nutrient and light values (Sternberg and Shoshany, 2001; Yuan et al., 2015). Soil water availability has been recognized as a key factor affecting the cover and biomass of road slope vegetation, and it is assumed to be the decisive factor contributing to the composition, structure and density of plant communities in areas with less than 600 $\mathrm{mm}$ of precipitation annually (Feng, et al., 2012). The SWC between the shady and sunny aspects was notsignificantlydifferentin our study $(\mathrm{F}=0.465$, $\mathrm{P}=0.63$ ), and this may have occurred because the road surfaces could catch rainfall and supply an additional water to the adjacent road slope (Feng et al., 2012). Thus, slope aspect was not a dominant factor influencing soil and plant characteristics during embankment restoration.

Previous studies have also shown that the amelioration of soil physical and chemical properties is strongly related to the age of the vegetation stand (Li et al., 2007; Zhu et al., 2010; Wang et al., 2015). C.varia L., which can fix nitrogen with its roots, significantly enriched SOC, TN, NN, AN, and TP in this study. Additionally, vegetation cover has significant effects on soil properties, primarily through the input of organic matter to the soil via the carbon and energy supplied from root exudates and plant remains (Rutigliano et al., 2004). On the other hand, C. varia L. can maintain high biomass and vegetation cover over the long-term on the roadslope, which is very important for controlling soil erosion and maintaining soil fertility (Yuan et al., 2015). Accelerating the recovery and promotion of SOC is a fundamental and effective method for stabilizing soil structure (Gregorich et al., 2003) and in this study, SOC is positively related to $\mathrm{TN}, \mathrm{NN}, \mathrm{AN}$, and $\mathrm{TP}$ (Table 3 ), which emphasize the central role of SOC in determining soil quality (Adak et al., 2014; Gregorich et al. 2003). In addition, the reduction of soil BD indicated that the soil structure had been improved (Zhu et al., 2010). Therefore, restoration with C.varia L. can enhance soil quality over time, and return it to the level of natural grassland after 20 years.

As expected, the results of this study indicated that the responses of plant properties were dependent on stand age. We found that plant diversity and richness varied greatly among treatments with stand age, but there was no consistent relationship between plant diversity and richness $(\mathrm{P}<0.05$, Table 3$)$. The plant cover in the S4 treatment was lower than that of S10 and $\mathrm{S} 20$, but the $S$ value was greater than that of S10 and $\mathrm{S} 20$. Due to the lower plant cover in S4, there were 
additional resources and light available to facilitate the growth of other species (Hautier et al., 2009), but the suppression of plant species and the establishment of late-successional species decreased with stand age as competition for light and nutrient increased. Plant diversity and species number stabilized after C.varia L. had been established for 10 years.

Table 3. Pearson correlation coefficients among stand age, slope aspect (Asp), Shannon-Wiener index $(H)$, Menhinick index $(\mathrm{Me})$, species number $(S)$, plant cover, soil water content (SWC), bulk density (BD), soil organic carbon (SOC), total nitrogen (TN), total phosphorus (TP), available phosphorus (AP), ammonium nitrogen (AN) and nitrate nitrogen $(\mathrm{NN})$.

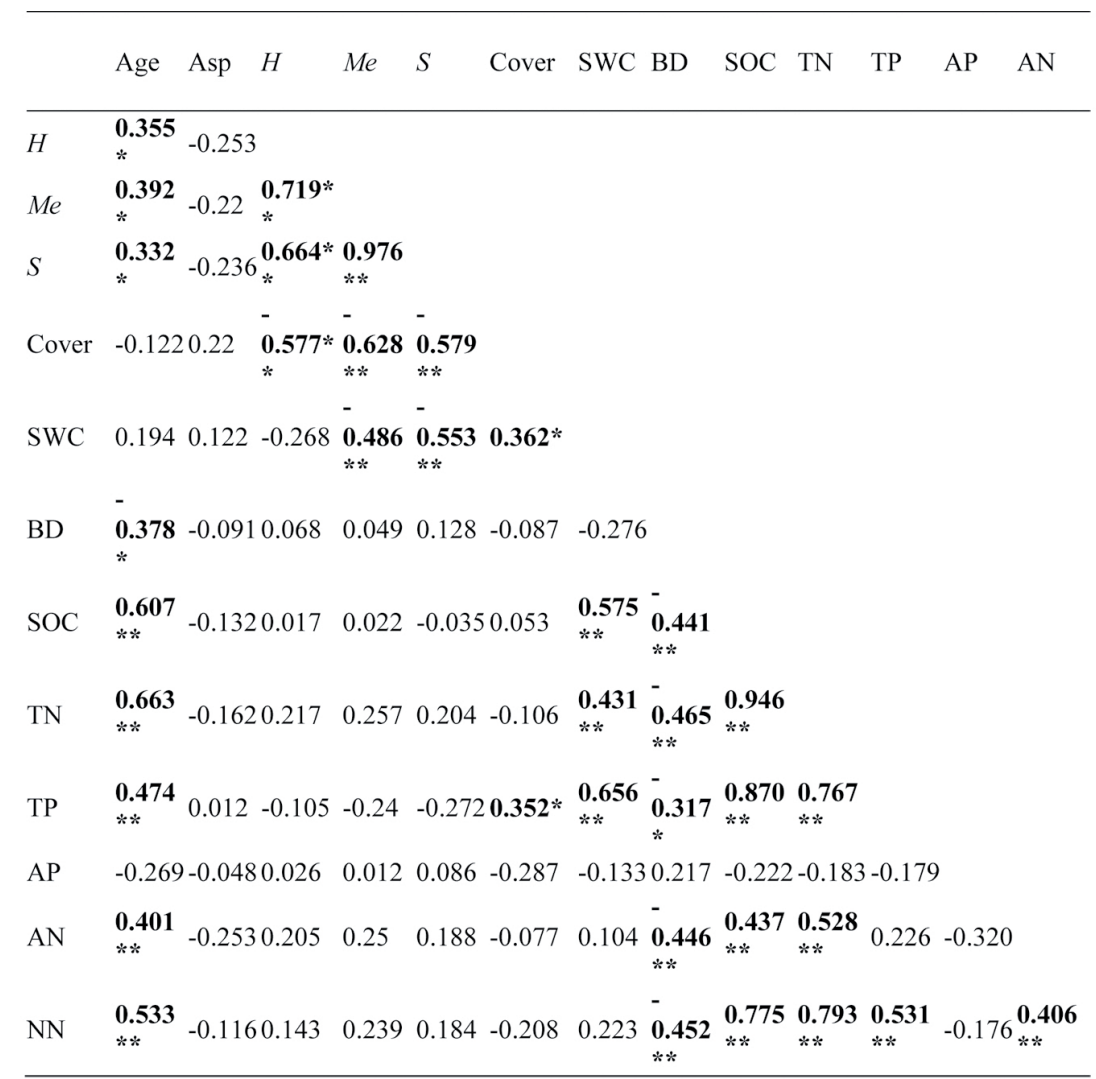

*Correlation is significant at the 0.05 level (2-tailed).

**Correlation is significant at the 0.01 level (2-tailed). 


\section{Conclusion}

We use the 'space-for-time' substitution to test whether plant and soil properties are determined by the slope aspect and stand age of legume plantations on embankments under identical climatic conditions. As expected, stand age was the main factor influencing the soil and plant feedback, but slope aspect had no effect on plant diversity in this study given the same soil water content. Planting $C$. varia $\mathrm{L}$. on the embankments could enhance soil nutrients and improve soil quality to the level of natural grassland after 20 years of plantation. $C$. varia $\mathrm{L}$. showed strong competitiveness and was a suitable species for embankments revegetation in the study region.

\section{References}

Adak, T., Singha, A., Kumar, K., Shukla, S.K., Singh, A., Kumar Singh, V. 2014. Soil organic carbon, dehydrogenase activity, nutrient availability and leaf nutrient content as affected by organic and inorganic source of nutrient in mango orchard soil. J. Soil Sci. Plant Nut. 14, 394-406.

Angold, P.G. 1997. The impact of a road upon adjacent heathland vegetation: effects on plant species composition. J. Appl. Ecol. 34, 409-417.

Bochet, E., García-Fayos, P. 2004. Factors controlling vegetation establishment and water erosion on motorway slopes in Valencia, Spain. Restor. Ecol. 12, 166-174.

Callaham, M.A., Rhoades, C.C., Heneghan, L. 2008. A striking profile: soil ecological knowledge in restoration management and science. Restor. Ecol. 16, 604-607.
Cape, J.N., Tang, Y.S., van Dijk, N., Love, L., Sutton, M.A., Palmer, S.C.F. 2004. Concentrations of ammonia and nitrogen dioxide at roadside verges, and their contribution to nitrogen deposition. Environ. Pollut. 132, 469-478.

Coffin, A.W. 2007. From roadkill to road ecology: a review of the ecological effects of roads. J. Transpo. Geo. 15, 396-406.

Council, A.C.S. 1983. Soil Science Society of China. General analysis methods of soil and agricultural chemistry. Science Press, Beijing.

Eviner, V.T., Hawkes, C.V. 2008. Embracing variability in the application of plant-soil interactions to the restoration of communities and ecosystems. Restor. Ecol. 16, 713-729.

Feng, L., Li, X.R., Zhang, J.G., Li, X.J., Su, J.Q. Vegetation alteration in response to highway construction in the desertified steppe zone of the Tengger Desert, North China. Arid Land Res. Manag. 26, 59-78.

Forman, R.T. 2000. Estimate of the area affected ecologically by the road system in the United States. Conserv. Biol. 14, 31-35.

Forman, R.T., Deblinger, R.D. 2000. The ecological road-effect zone of a Massachusetts (USA) suburban highway. Conserv. Biol. 14, 36-46.

García-Palacios, P., Bowker, M.A., Maestre, F.T., Soliveres, S., Valladares, F., Papadopoulos, J., Escudero, A. Ecosystem development in roadside grasslands: biotic control, plant-soil interactions, and dispersal limitations. Ecol. Appl. 2011. 21, 2806-2821.

Grant, A.S., Nelson, C.R., Switalski, T.A., Rinehart, S.M. 2011. Restoration of Native Plant Communities after Road Decommissioning in the Rocky Mountains: Effect of Seed-Mix Composition on Vegetative Establishment. Restor. Ecol. 19, 160-169. 
Gregorich, E., Beare, M., Stoklas, U., St-Georges, P. 2003. Biodegradability of soluble organic matter in maize-cropped soils. Geoderma. 113, 237-252.

Hautier, Y., Niklaus, P.A., Hector, A. 2009. Competition for light causes plant biodiversity loss after eutrophication. Science. 324, 636-638.

Heneghan, L. Miller, S.P., Baer, S., Callaham, M.A., Montgomery, J., Pavao-Zuckerman, M., Rhoades, C.C., Richardson, S. 2008. Integrating soil ecological knowledge into restoration management. Restor. Ecol. 16, 608-617.

Jáuregui, B.M., Rivera, D., Peco, B. 2013. Does topsoil accelerate the decomposition of litter on roadslopes?. Ecol. Engin. 52, 88-95.

Jimenez, M., Ruiz-Capillas, P., Mola, I., P.rezCorona, E., Casado, M., Balaguer, L. 2013. Soil development at the roadside: a case study of a novel ecosystem. Land Degrad. Dev. 24, 564-574.

Li, X., Kong, D., Tan, H., Wang, X. 2007. Changes in soil and vegetation following stabilisation of dunes in the southeastern fringe of the Tengger Desert, China. Plant Soil. 300, 221-231.

Liu, S.L., Cui, B.S. Dong, S.K., Yang, Z.F., Yang, M., Holt, K. 2008. Evaluating the influence of road networks on landscape and regional ecological risk - a case study in Lancang River Valley of Southwest China. Ecol. Engin. 34, 91-99.

Madej, M.A., Seney, J., Mantgem, P. 2012. Effects of Road Decommissioning on carbon stocks, losses, and emissions in north Coastal California. Restor. Ecol. 21, 439-446.

Maren, I.E., Karki, S., Prajapati, C., Yadav, R.K., Shrestha, B.B. 2015. Facing north or south: Does slope aspect impact forest stand characteristics and soil properties in a semiarid trans-Himalayan valley?. J. Arid. Env. 121, 112-123.
Merino, C., Nannipieri, P., Matus, F. 2015. Soil carbon controlled by plant, microorganism and mineralogy interactions. J. Soil Sci. Plant Nut. 15, 321-332.

Olsen SR, S.L., 1982. Phosphorus. In: Page AL, Miller RH, Keeney DR (eds) Methods of soil analysis part 2: chemical and microbiological properties, 2nd ed. American Society of Agronomy, Soil Science Society of America, Madison, WI, pp 403-430.

Rumpel, C., Crème, A., Ngo, P.T., Velásquez, G., Mora, M. L., Chabbi, A.The impact of grassland management on biogeochemical cycles involving carbon, nitrogen and phosphorus. 2015. J. Soil Sci.Plant Nut. 15, 353-371.

Rutigliano, F., D’ascoli, R., Virzo De Santo, A. 2004. Soil microbial metabolism and nutrient status in a Mediterranean area as affected by plant cover. Soil Biol. Biochem. 36, 1719-1729.

Sternberg, M., Shoshany, M.2001. Influence of slope aspect on Mediterranean woody formations: comparison of a semiarid and an arid site in Israel. Ecol. Res. 16, 335-345.

Sun, H., Wang, C., Wang, X., Rees, R. 2013. Changes in soil organic carbon and its chemical fractions under different tillage practices on loess soils of the Guanzhong Plain in north-west China. Soil Use Manag. 29, 344-353.

Wang, J.J., Hu, C.X., Bai, J., Gong, C.M. 2015. Carbon sequestration of mature black locust stands on the Loess Plateau, China. Plant Soil Environ. 61, 116-121.

Warren, I., Robert, J. 2010. An experimental test of well: described vegetation patterns across slope aspects using woodland herb transplants and manipulated abiotic drivers. New Phytol. 185, 1038-1049. 
Yuan, Z. Q., Epstein, H., Li, F. M. 2015. Factors affecting the recovery of abandoned semi-arid fields after legume introduction on the Loess Plateau. Ecol. Engin. 79, 86-93.
Zhu, B., Li, Z., Li, P., Liu, G., Xue, S. 2010. Soil erodibility, microbial biomass, and physicalchemical property changes during long-term natural vegetation restoration: a case study in the Loess Plateau, China. Ecol. Res. 25, 531-541. 